Volodymyr H. Dziubenko ${ }^{1}, \mathrm{PhD}$, associate professor of Department of Labour and Environment Protection

ORCID ID: 0000-0003-2468-2555e-mail: illay19@ukr.net

Viktor O. Mileikovskyi ${ }^{1}, \mathrm{PhD}$, docent, associate professor of Heat Gas Supply and Ventilation department

ORCID ID: 0000-0001-8543-1800e-mail:v_mil@ukr.net

Illa A. Sachenko' ${ }^{2}$, engineer

e-mail: illay19@ukr.net

${ }^{1}$ Kyiv National University of construction and architecture, Kyiv, Ukraine

${ }^{2}$ Altis Construction, Kyiv, Ukraine

\title{
EXPANSION OF THE RANGE OF WET AIR I-D DIAGRAM FOR ENVIRONMENTAL SAFE HEAT PRODUCTION
}

\begin{abstract}
For environment protection, condensing boilers may be used instead of emission of high temperature combustion products. For condensing combustion, high moisture content in exhaust gases is typical. I-d diagram can be used for condensing economizer development, but it is primary built for heating, ventilation and air conditioning. In the work, new approach to build I-d diagram is proposed that allow widening of the range of parameters without precision loose. It allows obtaining higher precision for calculation of condensing economizers.

Keywords: exhaust gases; condensing boiler; condensing economizer; I-d diagram; wet air; enthalpy.
\end{abstract}

\section{Introduction}

The most environment-safe technology of fuel combustion is condensing boiler. It saves from $3 \%$ (by the datasheets of ÖkoFEN, 2015) of hard fuel to $10 \ldots 12 \%$ of gas fuel. There is a less volume of combustion products. Some pollutants are absorbed by the condensate. They can be utilised more easily than from the smoke. One of the problems developing the condensing heat exchangers is precise calculation of the thermodynamic processes. The most easier tool for wet air calculations is I-d diagram also known as Ramzin diagram or Mollier diagram. The main purpose of it is heating, ventilation and air conditioning (HVAC) systems. Often, laboratory researches of heat-mass transfer in the condensing heat exchangers are performed on very wet and hot air. Authors tried using the diagram for researches for new condensing polymer economizer [1]. Precision of the calculations was not enough because the basic parameters of enthalpy calculation are heat of vaporization and isobaric specific heat at temperature $t=0{ }^{\circ} \mathrm{C}$. In is enough for HVAC systems because of low temperature range - up to $40^{\circ} \mathrm{C}$. In the temperature range of condensing heat exchangers - up to $100{ }^{\circ} \mathrm{C}$ and higher, - the physical properties are different from the values above. To avoid difficult integration, the averaged values in the range of experimental studies are used. But an universal precision tool that can be used in the wide temperature range from HVAC to combustion systems may be preferred. 


\section{Basic equations for I-d diagram building}

Relative humidity can be found from the following equation using the pressure of saturated vapour $p_{\text {sat }}[\mathrm{Pa}]$ :

$$
\varphi=p_{\text {vap }} / p_{\text {sat }}
$$

The work [2] uses very rough quadratic approximation of the pressure of saturated vapour. Moisture content $d[\mathrm{~kg} / \mathrm{kg}$ dry air $]$ is dependent on partial pressure of the vapour $p_{\text {vap }}[\mathrm{Pa}]$ and the pressure of the process $p[\mathrm{~Pa}]$ (usually equal to the barometric pressure):

$$
d=0.623 p_{\text {vap }} /\left(p-p_{\text {vap }}\right)=0.623 \varphi p_{\text {sat }} /\left(p-\varphi p_{\text {sat }}\right)
$$

In the equation (2) 0.623 is the ratio between the specific gas constant for the dry air and the vapour $R_{\text {d.a. }} / R_{\text {vap }}$. The precise value, used in this work, is $R_{\text {d.a. }} / R_{\text {vap }}=18.016 / 28.96=0.6221$.

The standards of I-d diagram building are described in the work [2]. The enthalpy $[\mathrm{kJ} / \mathrm{kg}$ dry air] can be calculated by the following simplified formula:

$$
I=1.005 t+(2500+1,8 t) d
$$

In the equation (3) the numerical values are the physical properties at $t=0{ }^{\circ} \mathrm{C}$ : specific heat of the dry air $c_{\text {d.a. }}=1.005 \mathrm{~kJ} /(\mathrm{kg} \mathrm{K})$, of the moisture (vapour) $c_{\text {vap. }}=1.8 \mathrm{~kJ} /(\mathrm{kg} \mathrm{K})$ and the heat of vaporization of water $r=2500 \mathrm{~kJ} / \mathrm{kg}$. All of the values are dependent on temperature and will be represented below.

These equations are valid in temperature range of HVAC systems. If we need more precise calculations for wide temperature range, the equations will be more complex. If we pass any process from the starting point $\mathrm{O}\left(t=0^{\circ} \mathrm{C}, d=0\right)$ to some point $\mathrm{C}$ (with current enthalpy $\mathrm{I}\left[\mathrm{kg} / \mathrm{kg}\right.$ dry air], temperature $t\left[{ }^{\circ} \mathrm{C}\right]$ and moisture content $d$ [kg/kg dry air]), there are some non-answered questions, how to integrate the heat, required for the process. The most important is: what heat of vaporization $[\mathrm{kJ} / \mathrm{kg}]$ we need? It is dependent on the temperature. However, the vapour is superheated except the curve $\varphi=1$. Thus, what temperature does correspond to the vaporization?

\section{Principles for wide-range I-d diagram building}

To answer the question above, it is possible to use the property of isobaric processes that no work will is performed. All heat $q[\mathrm{~kJ} / \mathrm{kg}]$ necessary for a process is equal to the difference between ending and starting enthalpy $[\mathrm{kJ} / \mathrm{kg}]$ and independent on the process curve. Therefore, we can introduce a basic process (possible or fictitious) from a point with known enthalpy (the best choice is a point with $I=0$ ) to the calculation point $C$. The process may be easy calculated with minimum assumptions and simplifications (fig. 1). 


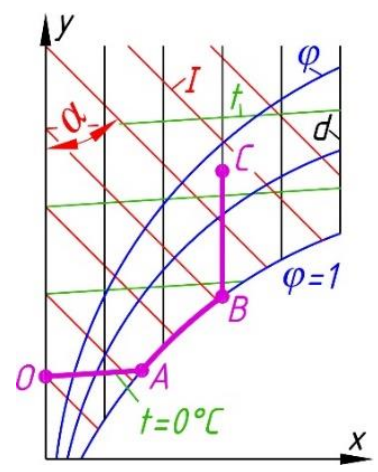

Fig. 1 - Scheme of I-d diagram with basic process

( $x$ and $y$ are the coordinates of graphic window for plotting, units)

We will start the basic process from the point $\mathrm{O}$ and perform it along three lines:

$\mathrm{OA}$ - isothermal humidification at $\left(t=0^{\circ} \mathrm{C}\right)$ up to $\varphi=1$ and the moisture content $d_{A}, \mathrm{~kg} / \mathrm{kg}$ dry air. As we have very low moisture content (up to $0.001 \mathrm{~kg} / \mathrm{kg}$ dry air), it is possible to use heat of vaporization at zero temperature $r_{0}=r\left(t=0{ }^{\circ} \mathrm{C}\right)$ without significant error. The necessary heat $[\mathrm{kJ} / \mathrm{kg}$ dry air $]$ is

$$
q_{O A}=r_{0} d_{\mathrm{A}}
$$

$\mathrm{AB}$ - the process of humidification and heating along the curve $\varphi=1$. The heat of the process consists of vaporization heat, heating of the dry air and the already vaporized water. The necessary heat $[\mathrm{kJ} / \mathrm{kg}$ dry air $]$ is

$$
q_{A B}=\int_{d_{A}}^{d} r d d_{s a t}+\int_{0}^{t_{B}} c_{d . a .} d t+\int_{0}^{d_{t_{B}}} c_{v a p} d\left(d_{s a t} t\right),
$$

where $d$ is the differential operator (straight and bold in contrast with moisture content - italic, not bold); $d_{\text {sat }}$ is the moisture content of the air at $\varphi=1$. It is called by the different index because it can be found easy.

$\mathrm{BC}$ - heating with constant moisture content $d[\mathrm{~kg} / \mathrm{kg}$ dry air]. The heat of the process consists of heating of the dry air and the vapour. The necessary heat $[\mathrm{kJ} / \mathrm{kg}$ dry air] is

$$
q_{B C}=\int_{t_{B}}^{t}\left(c_{\text {d.a. }}+c_{v a p} d\right) d t
$$

The enthalpy $[\mathrm{kJ} / \mathrm{kg}$ dry air] of the air at the calculation point $\mathrm{C}$ is equal to the sun of the equations (4-6)

$$
\begin{gathered}
I=q_{O A}+q_{A B}+q_{B C}= \\
=r_{0} d_{A}+\int_{d_{A}}^{d} r d d_{s a t}+\int_{0}^{t_{B}} c_{d . a .} d t+\int_{0}^{d_{t_{B}}} c_{v a p} d\left(d_{s a t} t\right)+\int_{t_{B}}^{t}\left(c_{d . a .}+c_{v a p} d\right) d t= \\
=r_{0} d_{A}+\int_{d_{A}}^{d}\left(r+c_{v a p} t\right) d d_{s a t}+\int_{0}^{t_{B}}\left(c_{d . a .}+c_{v a p} d_{s a t}\right) d t+\int_{t_{B}}^{t}\left(c_{d . a .}+c_{v a p} d\right) d t .
\end{gathered}
$$


Replacing the moisture content by the temperature in the first integral of the equation (7) can simplify the expression but cause additional derivative $d d_{\text {sat }} / d t$. The derivative can be found only using table data for saturated vapour pressure. This is possible only numerically with additional error and can be recommended only for rough calculations.

Physical properties of dry air and water vapour can be found by author's interpolations (preserving all table digits) of the data [3]. Specific heat $[\mathrm{kJ} /(\mathrm{kg} \cdot \mathrm{K})]$ in temperature ranges, corresponding, $t=-73,15 \ldots 276,85 \mathrm{C}$ and $t=0 \ldots 130 \mathrm{C}$

$$
\begin{gathered}
c_{\text {d.a. }}=(0.00394(t / 100)+0.0016)(t / 100)+1.00583 \\
c_{\text {vap }}=\left(\left(0.0352(t / 100)^{2}+0.1058\right)(t / 100)+0.0282\right)(t / 100)+1.86443 .
\end{gathered}
$$

Heat of vaporization $[\mathrm{kJ} / \mathrm{kg}$ ] by [3] with deviation of $0.087 \mathrm{~kJ} / \mathrm{kg}$ or $0.0038 \%$ at $t=0 \ldots 100^{\circ} \mathrm{C}$ :

$$
r=((5.434-12.85 \theta)(t / 100)-236.28)(t / 100)+2500.97
$$

Pressure of saturated vapour [Pa] can be found by the following author's interpolation (repeats all digits of the table data) of data in [4] at temperature range $t=0 \ldots 105^{\circ} \mathrm{C}$

$$
\begin{gathered}
p_{\text {sat }}=610.753+(442.91+(144.6448+(24.2836+(5.45193+(0.66836- \\
-0,006354(t / 10))(t / 10))(t / 10))(t / 10))(t / 10))(t / 10)+ \\
+\left(0.209-1.8172(t / 10)^{4}\right) \sqrt{t / 10}
\end{gathered}
$$

\section{Method of wide-range I-d diagram building}

From the equation (2) it is possible to find the pressure of saturated vapour at $\varphi=1$ :

$$
p_{\text {sat }}=\frac{p}{\frac{R_{\text {d.a. }} / R_{\text {vap }}}{d}+1}=\frac{p d}{\left(R_{\text {d.a. }} / R_{\text {vap }}\right)+d} \approx \frac{p}{\frac{0.623}{d}+1} .
$$

If temperature is known, the pressure can be found by numerical solution of the equation (11) at known pressure $p_{\text {sat }}[\mathrm{Pa}]$ and unknown temperature $t\left[{ }^{\circ} \mathrm{C}\right]$. Using the equation (12) it is possible to find the temperature $t\left[{ }^{\circ} \mathrm{C}\right]$ of saturated vapour using the moisture content $d[\mathrm{~kg} / \mathrm{kg}$ dry air] and the pressure $p[\mathrm{~Pa}]$.

By the equation (11) at zero temperature $p_{\text {sat }}(t=0)=610.753 \mathrm{~Pa}$. Therefore, by the expression (2) at the point A moisture content $[\mathrm{kg} / \mathrm{kg}$ dry air]:

$$
d_{A}=379.949 /(p-610.753)
$$

The equations (2) and (11) dives the opportunity to find moisture content on the line $\varphi=1$ at known temperature $t\left[{ }^{\circ} \mathrm{C}\right]$ and pressure $p[\mathrm{~Pa}]$.

If we create functions in computer algebra system (or using some programming language) by the equations (8-13), we can use it to calculate integrands in the expression (7). The integrals may be numerically computed using any quadrature formula. Desired precision can be achieved using some known adaptive quadrature 
algorithm. Therefore, the equation (7) can give enthalpy I [ $\mathrm{kJ} / \mathrm{kg}$ dry air] by known temperature $t\left[{ }^{\circ} \mathrm{C}\right]$, moisture content $d[\mathrm{~kg} / \mathrm{kg}$ dry air $]$ and pressure [Pa]. The function that computes it, is enough to build isotherms $(t=$ const) in coordinates $(I, d)$.

To operate with relative humidity, partial pressure of the vapour is necessary. It can be found from the equation (2):

$$
p_{\text {sat }}=p d /\left(\left(R_{\text {d.a. }} / R_{\text {vap }}\right)+d\right)
$$

Using the equations (14), solving the equation (11) and substituting the results to the function created by the equation (7) it is possible to build a function that calculates enthalpy at known moisture content $\mathrm{d}$ [kg/kg dry air], relative humidity $\varphi$, and pressure $p[\mathrm{~Pa}$. This function allows building curves of relative humidity $(\varphi=$ const) in coordinates $(I, d)$ at constant pressure $p[\mathrm{~Pa}]$.

I-d diagrams usually use oblique-angled coordinates. Lines of constant moisture content $[\mathrm{kg} / \mathrm{kg}$ dry air or $\mathrm{g} / \mathrm{kg}$ dry air] are vertical. Lines of constant enthalpy $[\mathrm{kJ} / \mathrm{kg}$ dry air] and vertical axis form an angle $\alpha$. One of the convenient values is $\alpha=\pi / 4$ (or $45^{\circ}$ ). Let us use scales for enthalpy $C_{I}$ [units $/(\mathrm{kJ} / \mathrm{kg}$ dry air)] and for moisture content $C_{d}$ [units $/(\mathrm{kg} / \mathrm{kg}$ dry air)]. As the value of the moisture content is very small, usually $C_{d}=1000$ units $/(\mathrm{kg} / \mathrm{kg}$ dry air) and the axis is often labelled in $\mathrm{g} / \mathrm{kg}$ dry air. The transformation to/from the euclidean coordinates $(x, y)$ [units] can be performed by the following equations:

$$
\begin{gathered}
x=C_{d} d . \\
y=C_{I} I-\frac{x}{\tan (\alpha)} . \\
d=x / C_{d} . \\
I=\left(y+\frac{x}{\tan \alpha}\right) / C_{I}=\frac{y \tan (\alpha)+x}{C_{i} \tan \alpha} .
\end{gathered}
$$

\section{Example of wide-range I-d diagram building}

Let us build an I-d diagram for standard barometric pressure $p=101325 \mathrm{~Pa}$ (Fig. 2). The calculations and plotting are performed in SciLab 5.5.2 [5-10].

Let us compare it with I-d diagram in the work [2]. The maximum moisture content is $30 \mathrm{~g} / \mathrm{kg}$ dry air or $0.03 \mathrm{~kg} / \mathrm{kg}$ dry air. The maximum value of temperature that allows easy take enthalpy at the maximum moisture content is $48{ }^{\circ} \mathrm{C}$. The corresponding enthalpy by the equations (7-13) is $124.79 \mathrm{~kJ} / \mathrm{kg}$ dry air. By [2] it is $125.8 \mathrm{~kJ} / \mathrm{kg}$ dry air. The deviation by enthalpy is $0.8 \%$. At the same moisture content, but the temperature $32{ }^{\circ} \mathrm{C}$ the enthalpy is, corresponding, $107.77 \mathrm{~kJ} / \mathrm{kg}$ dry air and $108.9 \mathrm{~kJ} / \mathrm{kg}$ dry air. The deviation is $1.05 \%$. It is enough for engineering calculations. 


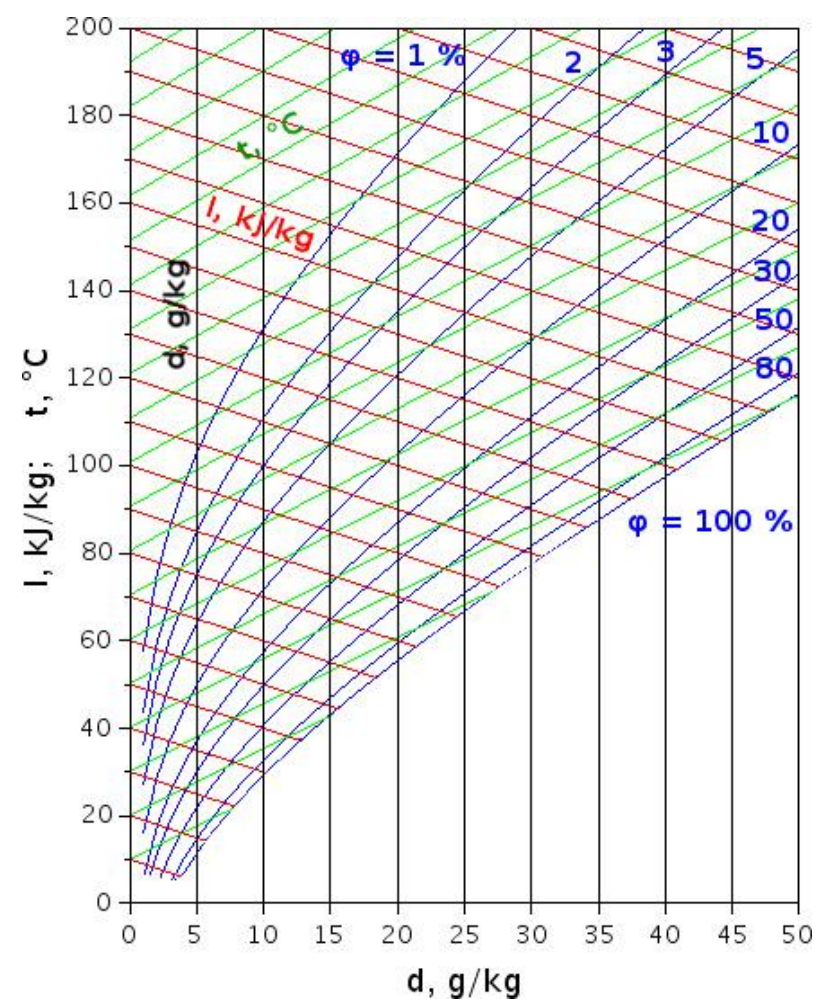

Fig. 2 - Fragment of I-d diagram for $p=101325 \mathrm{~Pa}$

At moisture content $15 \mathrm{~g} / \mathrm{kg}$ dry air or $0.015 \mathrm{~g} / \mathrm{kg}$ dry air and temperature $24{ }^{\circ} \mathrm{C}$ the enthalpy has no deviation: $62 \mathrm{~kJ} / \mathrm{kg}$ dry air. At the same moisture content and temperature $60{ }^{\circ} \mathrm{C}$ the corresponding values of enthalpy are $99.30 \mathrm{~kJ} / \mathrm{kg}$ dry air and $99.5 \mathrm{~kJ} / \mathrm{kg}$ dry air. The deviation is comparable with line thickness on the diagram [2].

At moisture content $4 \mathrm{~g} / \mathrm{kg}$ dry air or $0.004 \mathrm{~g} / \mathrm{kg}$ dry air and temperature $4{ }^{\circ} \mathrm{C}$ the enthalpy has no deviation: $14.06 \mathrm{~kJ} / \mathrm{kg}$ dry air. At the same moisture content and temperature $60{ }^{\circ} \mathrm{C}$ the corresponding values of enthalpy are $70.86 \mathrm{~kJ} / \mathrm{kg}$ dry air and $70.8 \mathrm{~kJ} / \mathrm{kg}$ dry air. The deviation is comparable with line thickness on the diagram [2].

Therefore, the enthalpy deviation is near to zero, but at the right part, close to $d=0.030 \mathrm{~kg} / \mathrm{kg}$ dry air, it has tendency of increasing. At high moisture content, typical for condensing economizers, the deviation may reach $3 \%$ - energy saving of hard fuel condensing boilers. Let us test a point, typical for the economizers: $t=60^{\circ} \mathrm{C}, d=0.1 \mathrm{~kg} / \mathrm{kg}$ dry air. The equation [2]

$I=1.005 t+(2500+1.8 t) d=1.005 \cdot 60+(2500+1.8 \cdot 60) \cdot 0.1=321.1 \mathrm{~kJ} / \mathrm{kg}$ dry air

By the equations (7-13) the value is $I=313.33 \mathrm{~kJ} / \mathrm{kg}$ dry air. The deviation is $7.8 \mathrm{~kJ} / \mathrm{kg}$ dry air or $2.5 \%$. It is comparable with energy saving on hard fuel condensing boiler (near to $3 \%$ ). We can make a mistake calculating such devices up to twice. At moisture content $d=0.2 \mathrm{~kg} / \mathrm{kg}$ dry air the deviation reaches $3.3 \%$.

If we use standard I-d diagram, we need to include the deviation into the total uncertainty of the experimental results. This can be avoided using proposed method.

Therefore, the standard I-d diagrams are acceptable for rough calculations. For more precise calculations, the proposed method is recommended. 


\section{Conclusions}

Proposed method provides results that have good agreement with I-d diagrams for HVAC. At high temperature and moisture content the results allow refining the diagram. The deviation is comparable with energy saving of hard fuel condensing boilers (3\%). Therefore, the standard I-d diagrams are acceptable for rough calculations. For more precise calculations, the proposed method is recommended.

\section{REFERENCES (TRANSLATED AND TRANSLITERATED)}

1. Dzjubenko V.G. Doslidzhennja plivkovyh teploobminnykiv dlja kondensacijnyh kotloagregativ indyvidual'nogo teplopostachannja / V.G. Dzjubenko // Mistobuduvannja ta terytorial'ne planuvannja: Nauk.-tehn. zbirnyk. - K.: KNUBA, 2015. - Vyp. 57. - S. 163-168. (in Ukrainian)

2. Otoplenie I ventiljacija: uchebnik dlja VUZov. V 2 ch. Ch. 2. Ventiljacija / red. V.N. Bogoslovskij. - M.: Strojizdat, 1976. - 439 s. (in Russian)

3. Vargaftik N.B. Spravochnik po teplofizicheskim svojstvam gazov i zhidkostej / N.B. Vargaftik. - M.: Nauka, 1972. - 720 s. (in Russian)

4. Fizicheskie velichiny: Spravochnik / Pod red. I.S. Grigor'eva, E.Z. Mejlihova. - M.: Jenergoatomizdat, 1991. - 1232 s. (in Russian)

5. Affouf M. Scilab by examples / M. Affouf. - CreateSpace, 2012. - 114 p. (in English)

6. Hema Ramachandran. SciLab (A Free Software to MatLab) / Hema Ramachandran, Achuthsankar S Nair. - S. Chand Publishing, 2012. - 216 p. (in English)

7. Vande Wouwer A. Simulation of ODE/PDE Models with MATLAB ${ }^{8}$, OCTAVE and SCILAB: Scientific and Engineering Applications / A. Vande Wouwer, P. Saucez, C.V. Fernández. - Springer, 2014. - 406 p. (in English)

8. Roux P. SciLab. From Theory to Practice P. I. Fundamentals / P. Roux. Translated by P. Mathieu. - France.: SciLab Enterprises, 2016. - 410 p. (in English)

9. Audibert T., Oussalah A. Informatique. Programmation et calcul scientifique en Python et SciLab / T. Audibert, A. Oussalah. - France.: Ellipses, 2014. - 528 p. (in English)

10. Faes G. Scilab: Eine Einführung in das Mathematikprogramm Scilab. - Deutchland.: Herstellung und Verlag, 2014. - 216 s.

\section{REFERENCES}

1. Дзюбенко В.Г. Дослідження плівкових теплообмінників для конденсаційних котлоагрегатів індивідуального теплопостачання / В.Г. Дзюбенко // Містобудування та територіальне планування: Наук.-техн. збірник. - К.: КНУБА, 2015. - Вип. 57. C. $163-168$.

2. Отопление и вентиляция: учебник для ВУЗов. В 2 ч. Ч. 2. Вентиляция / ред. В.Н. Богословский. - М.: Стройиздат, 1976. - 439 с.

3. Варгафтик Н.Б. Справочник по теплофизическим свойствам газов и жидкостей / Н.Б. Варгафтик. - М.: Наука, 1972. - 720 с.

4. Физические величины: Справочник / Под ред. И.С. Григорьева, Е.3. Мейлихова. М.: Энергоатомиздат, 1991. - $1232 \mathrm{c.}$

5. Affouf M. Scilab by examples / M. Affouf. - CreateSpace, 2012. - 114 p.

6. Hema Ramachandran. SciLab (A Free Software to MatLab) / Hema Ramachandran, Achuthsankar S Nair. - S. Chand Publishing, 2012. - 216 p.

7. Vande Wouwer A. Simulation of ODE/PDE Models with MATLAB ${ }^{8}$, OCTAVE and SCILAB: Scientific and Engineering Applications / A. Vande Wouwer, P. Saucez, C.V. Fernández. - Springer, 2014. - 406 p.

8. Roux P. SciLab. From Theory to Practice P. I. Fundamentals / P. Roux. Translated by P. Mathieu. - France.: SciLab Enterprises, 2016. - 410 p. 
9. Audibert T., Oussalah A. Informatique. Programmation et calcul scientifique en Python et SciLab / T. Audibert, A. Oussalah. - France.: Ellipses, 2014. - 528 p.

10. Faes G. Scilab: Eine Einführung in das Mathematikprogramm Scilab. - Deutchland.: Herstellung und Verlag, 2014. - 216 s.

Text of the article was accepted by Editorial Team 23.02.2018

\section{В.Г. Дзюбенко, В.О. Мілейковський, І.А. Саченко \\ РОЗШИРЕННЯ ДІАПАЗОНУ I-D ДІАГРАМИ ВОЛОГОГО ПОВІТРЯ ДЛЯ ЕКОЛОГІЧНО БЕЗПЕЧНОГО ВИРОБНИЦТВА ТЕПЛОТИ}

Анотація. Для захисту навколишнього середовища замість викидів високотемпературних продуктів згоряння можуть використовуватися конденсаційні котли. Для конденсаційних котлів типовим є високий вологовміст відвідних газів. I-d діаграма може бути використана для розробки конденсаційних економайзерів, однак вона побудована в першу чергу для опалення, вентиляції та кондиціонування повітря. У роботі запропоновано новий підхід до побудови I-d діаграми, що дозволяє розширити діапазон параметрів без втрати точності. Це дозволяє отримати більш високу точність для розрахунку конденсаційних економайзерів.

Ключові слова: відвідні гази; конденсаційний котел; конденсаційний економайзер; I-d діаграма; вологе повітря; ентальпія.

\section{Автори (науковий ступінь, вчене звання, посада):}

\section{Дзюбенко Володимир Григорович}

кандидат технічних наук, доцент кафедри охорони праці та навколишнього середовища Київський національний університет будівництва та архітектури

Адреса робоча: 03037 Україна, м. Київ, проспект Повітрофлотський, 31, а. 241

ORCID ID: 0000-0003-2468-2555e-mail: illay19@ukr.net

\section{Мілейковський Віктор Олександрович}

кандидат технічних наук, доцент кафедри теплогазопостачання і вентиляції Київський національний університет будівництва та архітектури

Адреса робоча: 03037 Україна, м. Київ, проспект Повітрофлотський, 31, а. 288

ORCID ID: 0000-0001-8543-1800 e-mail:v_mil@ukr.net

\section{Саченко Ілля Анатолійович}

інженер

ТОВ "Альтіс-констракшн"

Адреса робоча: 03126 Україна, м. Київ, вул. Качалова, 5-В

e-mail: illay19@ukr.net 